\title{
Acute Toxicity and Hepatotoxicity Evaluation of Methanol Extract of Root Bark of Calotropis gigantea in Rats
}

\section{Kartini Hasballah ${ }^{1}$, Murniana Sarong ${ }^{2}$, Renzavaldy Rusly ${ }^{3}$, Karina Tantri ${ }^{4}$ and Vera Dewi Mulia ${ }^{5}$}

\author{
${ }^{1}$ Faculty of Medicine, Syiah Kuala University, Banda Aceh-Indonesia \\ ${ }^{2}$ Faculty of Mathematic and Natural Sciences, Syiah Kuala University, Banda Aceh-Indonesia \\ ${ }^{3}$ Faculty of Medicine, Padjadjaran University, Bandung-Indonesia \\ ${ }^{4}$ Faculty of Medicine, Syiah Kuala University, Banda Aceh-Indonesia \\ ${ }^{5}$ Departement of Anatomical Pathology, Faculty of Medicine, Syiah Kuala University, Banda Aceh 23111
}

(Received: September 12, 2018; Accepted: November 13, 2018; Published (web): December 10, 2018)

\begin{abstract}
Many studies of root extract of Calotropis gigantea have been done to prove its potential as anticancer, antimicrobial, etc. agent $C$. gigantea plant itself is very easy to grow in tropical countries. However, studies of acute toxicity of $C$. gigantea root extract has not been performed.The purpose of this research was to know the safety level, the chemical constituents, and the acute toxicity of methanol extract of $C$. gigantea root bark given orally on Rattus norvegicus in rats. C. gigantea root bark was extracted by using methanol. The methanol extract was suspended in $1 \%$ sodium carboxymethyl cellulose (CMC) and administered orally by gavage $(1250,2500$ and 5000 $\mathrm{mg} / \mathrm{kg}$ ) in separate groups. On the day of fifteen, all animals were anesthetized and some selected vital organs were excised, weighed and macroscopically examined. The liver was assessed histopathologically. There were no lethal effects, behavioral changes and no significant change in body and organ weights compared to control after the administration of the extracts. Thus, the value of $\mathrm{LD}_{50}$ for oral administration of methanol extracts from root bark of C. gigantea was larger than $5000 \mathrm{mg} / \mathrm{kg}$. Methanol extract of $C$. gigantea root bark must be considered safe enough as none of the rats were died along the study. But, it can damage the hepatic cell, if given in higher dose.
\end{abstract}

Key words: Acute toxicity, Calotropis gigantea, heparhistopathology, $\mathrm{LD}_{50}$

\section{INTRODUCTION}

Calotropis gigantea is a plant that lives in tropical and subtropical regions and is commonly found in Indonesia, China, Burma, Bangladesh, India, Philippines, Pakistan, Thailand and Sri Lanka. ${ }^{1,2}$ This herb is useful in treating various disorders of the central nervous system, digestive system and respiratory system, reproductive system. ${ }^{3}$ Some parts of this plant such as leaves, stems, roots and flowers are traditionally used to treat various diseases such as tumors, fever, rheumatism, indigestion, cough, flu, asthma, nausea and diarrhea ${ }^{4}$. Ethnobotanically, the root of this plant is effective to ease the bile flowing

Correspondence to: Kartini Hasballah

E-mail: kartinirusly@gmail.com

Phone: +62811688778; Fax: +6265128333

Dhaka Univ. J. Pharm. Sci. 17(2): 243-250, 2018 (December) DOI: http://dx.doi.org/10.3329/dujps.v17i2.39182 into the intestine, skin healing infections, worms, cough asthma, bronchitis and dyspepsia. ${ }^{1}$

C. gigantea contains chemical compounds such as alkaloids, phenols, resins, amine, sitosterol, giganterol, isogiganterol, naphthalene, flavonol glycosides, triterpenoids, tannins, sterols, saponins and steroids. ${ }^{5}$ Previous research has reported that the plant's methanol extract and its root bark are active as insecticides against Tribolium castaneum larvae and Aedes aegypti larvae. ${ }^{6,7}$ Ethanol extract of $C$. gigantea root can more quickly heal wounds in rats. ${ }^{8}$ The methanol extract of $C$. gigantea root bark in chloroform has antitumor activity against carcinoma cells in mice. Ethyl acetate extract from roots of $C$. gigantea collected in Meherchandi, Bangladesh contains terpenoid and steroidal compounds and 
showed cytotoxic activity against Artemia salina with an $\mathrm{IC}_{50}$ value of $29.56 \mu \mathrm{g} / \mathrm{ml} .{ }^{9}$ The pregnanon class of compound, i.e. calotropon has inhibitory force against myelogenous leukemia cell lines K562 and gastric cancer SGC-7901 with $\mathrm{IC}_{50}$ values of 9.7 $\mu \mathrm{g} / \mathrm{ml}$ and $6.7 \mu \mathrm{g} / \mathrm{ml}^{10}$

The flower portion of the $C$. gigantea plant caused no death and changes in behavior patterns in test animals up to a dose of $2000 \mathrm{mg} / \mathrm{kg} .{ }^{11}$ However, research on toxicity of extract of $C$. gigantea root has not been done. Therefore, this study was conducted to test the toxicity in white rats (Rattus norvegicus) with quantitative data in the form of lethal dose 50 $\left(\mathrm{LD}_{50}\right)$. Data from $\mathrm{LD}_{50}$ can be used to identify a compound classified as highly toxic to non-toxic material, but it is also used to estimate dosing rates for other toxicological tests, such as subchronic and chronic toxicity. ${ }^{12}$ The aim of this study was to analyze the acute toxicity of methanol extract of C.gigantea root bark on white rats (Rattus norvegicus).

\section{MATERIALS AND METHODS}

The equipments included glassware, analytical balance scales (Sartorius, USA), blender (Miyako, Japan), test plate, filter paper, vacuum rotary evaporator (Heidolph, Germany), disposable syringe $1 \mathrm{ml}$ and $3 \mathrm{ml}$ (Terumo, Japan), sonde, animal scales (Ohaus, USA), minor surgical instruments, rat cage, microtome (Leica, Germany), water bath (Memmert, Germany), drying oven (Memmert, Germany), refrigerators (Sharp, Japan), and microscope (Leica, Germany).

The reagents used such as methanol, ethanol, ammonia, iron trichloride, chloroform, hydrochloric acid, sodium carboxy methyl cellulose, diethyl ether were obtained from CV Rudang Jaya, Medan, Indonesia. Xylol, hematoxylin, eosin were obtained from PT Menara Agung, Medan, Indonesia. Magnesium powder obtained from CV Global Scientific, Bandung, Indonesia. Mayer, Dragendroff, Wagner reagents, and Liebermann-Burchard reagents were obtained from Department of Chemistry, Faculty of Mathematics and Natural Sciences, Syiah
Kuala University, Banda Aceh. Formalin, and paraffin wax were supplied from PT Fajar Mas Murni, Medan, Indonesia. Pellet were supplied from PT Citra Ina Feed Mill, Jakarta, Indonesia.

Sample and test animal. The root bark of $C$. gigantea was obtained from Alue Naga village, Kecamatan Syiah Kuala, Banda Aceh and was authenticated in Herbarium Laboratory, Department of Biology, Faculty of Mathematics and Natural Sciences, Syiah Kuala University, Banda Aceh (No. 944/UN11.1.28/DT/2017). The test animals used in this study were three-month-old male Rattus norvegicus weighing 150-200 g obtained from Faculty of Veterinary Medicine, Syiah Kuala University, Banda Aceh. The ethical clearance has been obtained from Faculty of Medicine, Syiah Kuala University, Banda Aceh for animal experimentation (Approval No. 37/KE/FK/2017; dated 12 September 2017).

\section{METHODS}

Extraction process. The fresh root barks of $C$. gigantea $(3 \mathrm{~kg}$ ) were dried shading at room temperature to remove the water content. Root bark that has been dried, were blended to obtain fine powder. Then, the powder was macerated with methanol. The maceration process was done gradually over $3 \times 24$ hours. The extract obtained was filtered using a filter paper. The filtrate was collected and evaporated with a vacuum rotary evaporator to obtain the concentrated methanol extract and tested for the content of the secondary metabolites.

Test animal preparation. Male Rattus norvegicus was acclimatized for one week in order to adapt to the experimental enclosure environment. At this stage, the observation were carried out of the general state of the tested animals.

Preclinical test procedures. The design of this study was post-test only with control group design. Male Wistar rats $(\mathrm{n}=24)$ divided randomly into 3 groups as treated groups and 1 group as control group. 
Methanol extract of $C$. gigantea root bark was suspended in $1 \% \mathrm{CMC}$ and administered a single dose $(1250,2500$ and $5000 \mathrm{mg} / \mathrm{kg})$ in male rats $(R$. norvegicus) in each of 2, 3 and 4 groups, while group 1 (control) received $1 \% \mathrm{CMC}(\mathrm{n}=6)$ only. Before administering the extract, the rats were fasted overnight (drinking was given ad libitum). Feedback was taken 6 hours after administration of the test drug. The general behavior of rats was continuously monitored for 1 hour after administration of the extract, then periodically for the first 24 hours (with special attention given during the first 4 hours) and then daily for 14 days. After giving the dose of the test extract, observations were made on the development of body weight and toxic symptoms of the test animals and the number of deaths were calculated. During the experiment, observation of toxic symptoms was conducted in the skin, fur, eyes, mucous membranes and also respiratory, circulatory, autonomic, central nervous system, and for other behavioral changes. Special attention was given to observe tremors, convulsions, hypersalivation, diarrhea, lethargy, sleep and coma. On the fifteenth day, all animals were anesthetized with diethyl ether and selected vital organs such as brain, heart, lungs, kidneys, livers, spleen, testis, pancreas and gut were subsequently separated, weighed and examined macroscopically. Data on the number of deaths of first day test animals were used to calculate Lethal Dose $50\left(\mathrm{LD}_{50}\right)$ according to Weil, C.S.

Special liver organ was inserted into formalin for subsequent tissue fixed in glass preparations. Each preparation was observed using a microscope with 400 times magnification in five field of view and calculated the number of normal cells, the number of parenchymatically degenerated cells, hydropic degeneration and necrosis. The number of each cell was searched for the average to multiply by the score of Manja Roenigk. The results of the score summed up and obtained score damage to Manja Roenigk for one rat.

Data analysis. Data on the number of tested animal mortality were used to calculate $\mathrm{LD}_{50}$ values using Weil, C.S method which was then quantitatively used to evaluate the intensity (potential) of acute toxicity according to Loomis criteria. The formula used to calculate $\mathrm{LD}_{50}$ is:

$$
\log \mathrm{LD}_{50}=\log \mathrm{D}+\mathrm{d}(\mathrm{f}+1)
$$

Information: $\mathrm{D}=$ The smallest dose given, $\mathrm{d}=$ logarithm of multiple doses, $\mathrm{f}=$ factor (Weil table)

Observation data were be tested on its normality first by using Saphiro-Wilk test and homogeneity using Levene test. Where the data used was basic data that has not been processed into a frequency table. Data is interval or ratio scale and comes from random samples. The data was sorted and then divided into two groups to produce Saphiro-Wilk. ${ }^{13}$ The Levene test is inferential statistics that are used to assess variance equations for variables calculated for two or more groups. When the data is normally distributed and homogeneous, then it is continued with ANOVA test to determine whether there is any significant change between treatment groups. Furthermore, a Post Hoc Tukey test was conducted to determine which groups had the most significant differences. ${ }^{14}$

Observational data of histopathologic images of animal liver were tested for normality first using Saphiro-Wilk test and homogeneity using Levene test. Normally distributed and homogeneous data were then continued with ANOVA test to determine whether or not there was a significant difference between treatment groups. Next is the Post Hoc Duncan test to determine which groups have the most significant differences.

\section{RESULTS AND DISCUSSION}

Extraction and phytochemical test. The root bark of $C$. gigantea were dried and powdered to expand the surface to facilitate the extraction process whereby the solvent can penetrate the cell wall of the plant and accelerate the extraction process of the compound. The process of extraction was done by using maceration method where the sample was soaked with methanol. The extract was obtained as brown with $47.5 \mathrm{~g}$ of mass (yield: $1.58 \% \mathrm{w} / \mathrm{w}$ ).

Phytochemical analysis was performed on methanol extract of $C$. gigantea root bark. The 
purpose of phytochemical analysis was to know the class of secondary metabolite compounds contained in the sample. ${ }^{15}$ The methanol extract contained steroid, terpenoid, saponin and coumarin. The existence of steroids and terpenoids in the sample were marked by the color change to green and red after being reacted using the Libermann-Burchard reagent. Saponin positive test results were characterized by the formation of foam in the sample. The positive result of coumarin was characterized by flouresense on filter paper saturated with $\mathrm{NaOH}$. The results of the phytochemical analysis were consistent that the $C$. gigantea root bark contains secondary metabolites like saponins, terpenoids and steroids. ${ }^{1,16}$
Acute toxicity test of methanol extracts of $C$. gigantea root bark. In acute toxicity study, $C$. gigantea bw extract at a dose of $5000 \mathrm{mg} / \mathrm{kg}$ caused no mortality. Generally, the reduction in body weight and internal organ weights is a simple and sensitive index of toxicity after exposure to toxic substance.

The deadly effect was not observed after administration of a single dose of $C$. gigantea root bark bw extract $(1250,2500$ and $5000 \mathrm{mg} / \mathrm{kg}$ ) in all treatment and control groups (without the administration of the extract). Acute toxicity test results also can be seen in figure 1 and table 1. No significant changes in body weight of treated rats were compared with controls $(\mathrm{p}>0.05)$.

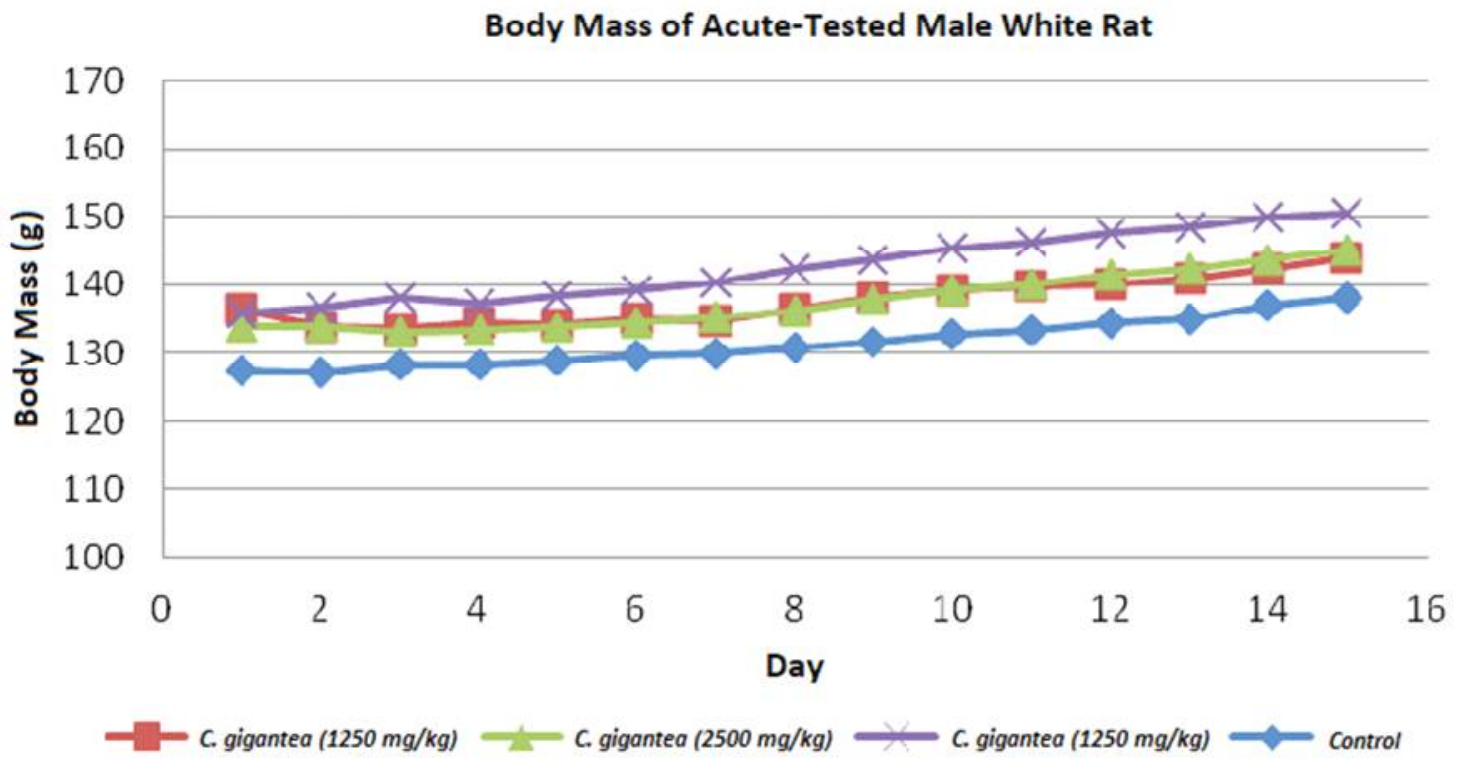

Figure 1. Effect of methanol extract of C.gigantea root bark on rats body weight.

In the current study, methanol extract of $C$. gigantea root bark $(1250,2500$, and $5000 \mathrm{mg} / \mathrm{kg})$ per oral did not significantly affect body weight and organs when compared to the control group. Thus, it was stated that the extract did not inhibit the growth of rats.

Microscopic results of histopathology. The histopathologic degree criteria for liver cells was scored by Manja Roenigk. The method of scoring by Manja Roenigk was to read every preparation of liver tissue in five different views and the center of the preparation with $400 \mathrm{x}$ magnification. Then each discussion counted 20 hepatocytes and multiplied by the score of each cell. The score of each cell as been shown in table $2 .{ }^{17}$ 
Table 1. Effect of administration of methanol extract of $C$. gigantea root bark on rats organ weight.

\begin{tabular}{|c|c|c|c|c|}
\hline \multirow{3}{*}{ Organ } & \multicolumn{4}{|c|}{ Treatment } \\
\hline & \multirow{2}{*}{ Control } & \multicolumn{3}{|c|}{ Methanol extract of $C$. gigantea root bark } \\
\hline & & $1250 \mathrm{mg} / \mathrm{kg}$ & $2500 \mathrm{mg} / \mathrm{kg}$ & $5000 \mathrm{mg} / \mathrm{kg}$ \\
\hline Brain & $1.68 \pm 0.05$ & $1.75 \pm 0.13$ & $1.63 \pm 0.10$ & $1.60 \pm 0.08$ \\
\hline Heart & $0.53 \pm 0.19$ & $0.55 \pm 0.06$ & $0.58 \pm 0.13$ & $0.65 \pm 0.06$ \\
\hline Lungs & $1.13 \pm 0.28$ & $1.45 \pm 0.19$ & $1.20 \pm 0.42$ & $1.55 \pm 0.44$ \\
\hline Kidney (Right) & $0.53 \pm 0.13$ & $0.58 \pm 0.10$ & $0.53 \pm 0.26$ & $0.65 \pm 0.13$ \\
\hline Kidney (Left) & $0.45 \pm 0.06$ & $0.55 \pm 0.06$ & $0.53 \pm 0.13$ & $0.58 \pm 0.10$ \\
\hline Liver & $6.10 \pm 1.24$ & $5.85 \pm 0.69$ & $5.70 \pm 1.64$ & $6.10 \pm 1.72$ \\
\hline Spleen & $0.70 \pm 0.12$ & $0.75 \pm 0.33$ & $0.50 \pm 0.40$ & $0.78 \pm 0.35$ \\
\hline Testis (Right) & $1.10 \pm 0.14$ & $1.05 \pm 0.06$ & $0.90 \pm 0.29$ & $0.98 \pm 0.26$ \\
\hline Testis (Left) & $1.15 \pm 0.17$ & $1.05 \pm 0.13$ & $0.93 \pm 0.24$ & $1.13 \pm 0.31$ \\
\hline Pancreas & $0.45 \pm 0.17$ & $0.33 \pm 0.13$ & $0.38 \pm 0.15$ & $0.33 \pm 0.05$ \\
\hline Gaster & $1.23 \pm 0.39$ & $1.30 \pm 0.24$ & $1.50 \pm 0.41$ & $1.10 \pm 0.36$ \\
\hline
\end{tabular}

There was no significant change in the weight of vital organs of treated male rats compared with controls ( $p>0.05)$.
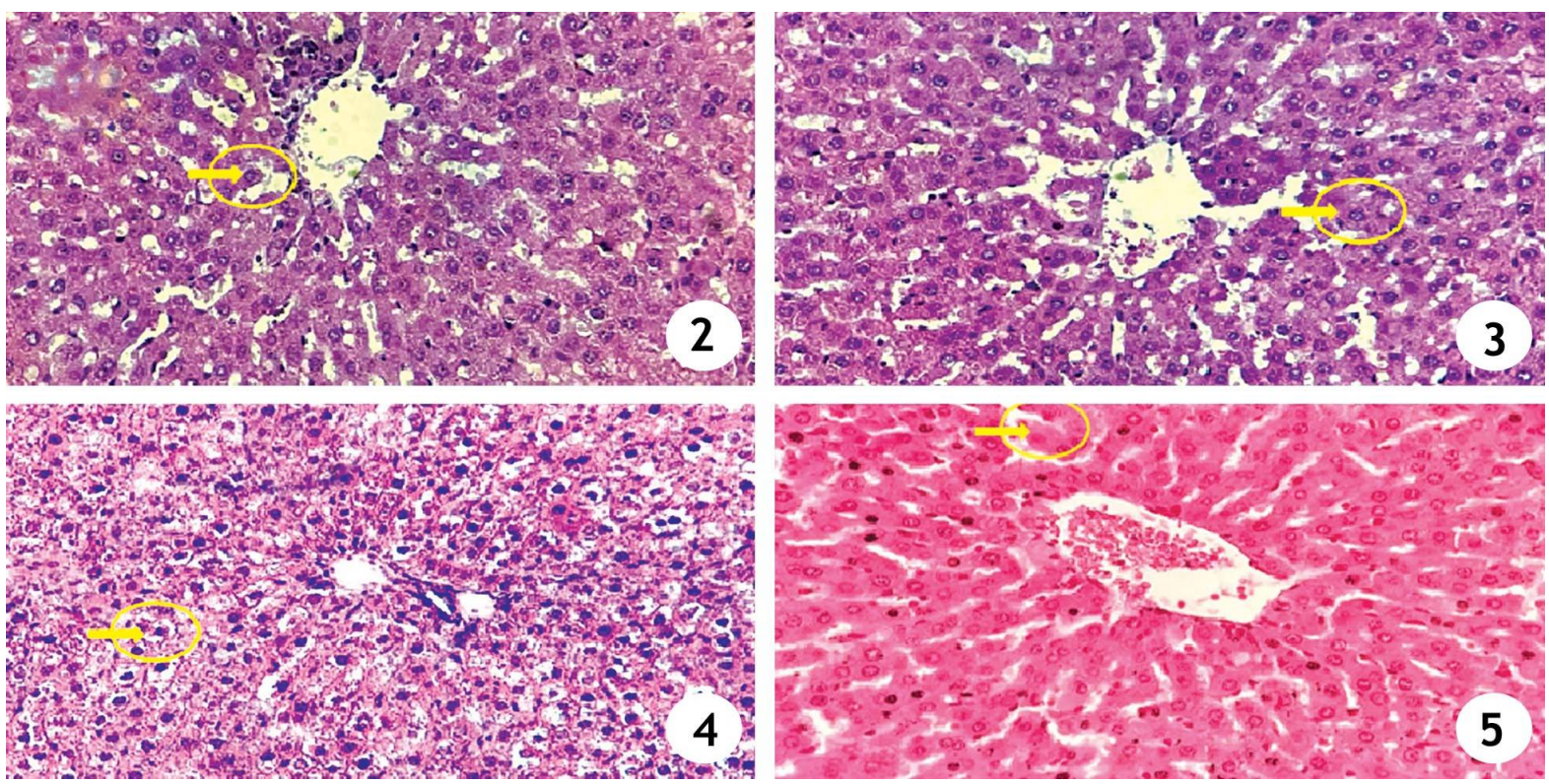

Figure 2. Histopathologic picture of rat liver cells of group 1 (control) with 400x magnification. Yellow arrow: normal cells (score 1). Figure 3. Histopathologic picture of rat liver cells (group 2) with 400x ruraling. Yellow *arrow: parenchymatous degeneration (score 2). Figure 4. Histopathologic picture of hepatic cell of rat (group 3) with 400x enlargement. Yellow arrow: hydropic degeneration (score 3). Figure 5. Histopathologic picture of rat liver cells (group 4) with 400x enlargement. Yellow arrow: hepatocyte necrosis (score 4)

Classification of cell damage was divided into parenchymatous degeneration, hydropic degeneration and necrosis. Parenchymatous degeneration is the mildest degeneration, due to the swelling and turbidity of the cytoplasm due to the emergence of granules in the cytoplasm due to protein precipitate.

This degeneration is reversible because it occurs only in the mitochondria and endoplasmic reticulum 
due to oxidative disorders. The affected cells can not eliminate the water so it is buried in the cell so that the cell swells. ${ }^{18}$ Hydropic degeneration is a more severe degeneration. In this degeneration a vacuolecontaining water in the cytoplasm contains no fat or glycogen, so the cytoplasm becomes pale and swollen with fluid build-up. Hydropic degeneration usually occurs due to metabolic disorders such as hypoxia or chemical toxicity. This degeneration is also reversible, but it may not be irreversible if the cause of the cancer persists. The injured cell will have a tear of the plasma membrane and a cell nuclear change that will result in cell death. ${ }^{19}$ Necrosis is a process of cell pathology if it has been injured. Necrosis is characterized by cytoplasmic changes and cell nuclei. The cytoplasmic changes of necrotic cells will show the increase of eosin color due to increased eosin bonds with cytoplasmic proteins. ${ }^{20}$

Tabel 2. Histopathologic degree criteria for liver Cells Manja Roenigk.

\begin{tabular}{ll}
\hline Damage Degree & Score \\
\hline Normal & 1 \\
Parenchymatous degeneration & 2 \\
Hydropic degeneration & 3 \\
Necrosis & 4 \\
\hline
\end{tabular}

Saphiro-Wilk normality test results showed normal distributed data and Levene Test showed homogeneous data with $\mathrm{p}>0.05$ and $95 \%$ confidence level. ANOVA test results obtained $\mathrm{p}=0,000$ $(\mathrm{p}<0.05)$, when indicates that there is a significant difference in histopathologic changes of hepar score. Data analysis with post hoc test showed that groups 2, 3 and 4 had significant differences with group 1 (control), with significance value $\mathrm{p}=0,000$ or $\mathrm{p}<0.05$. Post hoc test results shows greater liver damage in group 4.

In the acute toxicity study, administration of methanol extract of $C$. gigantea root bark with a dose of $5000 \mathrm{mg} / \mathrm{kg}$ orally showed no signs of mortality and changes in the behavior of rats compared with the control group. Classification of $\mathrm{LD}_{50}$ substances with values of 500 to 5000 , and between 5000 and
$15000 \mathrm{mg} / \mathrm{kg}$ each were considered to be slightly toxic and practically non-toxic. ${ }^{21}$ The result of this research stated that the extract of methanol of $C$. gigantea root bark has $\mathrm{LD}_{50}>5000 \mathrm{mg} / \mathrm{kg}$ orally and no detectable organ abnormality, so it was proven that the methanol extract of $C$. gigantea root bark was non-toxic.

Toxicity tests were conducted to evaluate the safety of traditional drugs that are often used by the community. $\mathrm{LD}_{50}$ from the root bark extract is categorized as a relatively harmless material. No mortality and behavioral changes were found in animals after given the $2000 \mathrm{mg} / \mathrm{kg}$ dose of $C$. gigantea flower extract. ${ }^{22}$ Examination of hepatic organ damage done by looking at histopathologic images of rat liver that have been given $C$. gigantea root bark extract and control by using a microscope. Based on the results of research from five field of view, it shows there are histopathologic changes of liver in the form of degeneration and necrosis.

The scores of histopathologic changes of hepatic cells increased in accordance with the increased dose of $C$. gigantea root bark extract.

The results of microscopic images showed changes in liver cells characterized by swelling of cells and the presence of empty space on the cytoplasm or the so-called degeneration. Cell degeneration is a condition in which the changes in cells and intercellular substances that result from disruption of metabolic processes in the cytoplasm resulting in morphologic changes of hepatic cells. ${ }^{23}$ Physiologically liver has a very remarkable regeneration capacity because the liver is an organ that can detoxify a chemical that is considered unimportant and harm the human body, but hepar is the organ that most often suffered cell damage. Hepatic cell regeneration occurs on day 14 after discontinuation of exposure. ${ }^{24}$

Liver damage can be caused by drugs or toxins. Drugs topical ingredients, supplements and environmental chemicals that enter the body will experience the process of absorption, distribution, metabolism and excretion. If a drug is given in large doses it can cause hepatotoxicity or damage to 
hepatic tissue due to toxic substances. Hepatotoxic substances known to cause hepatic cell damage will have the same effect on all individuals. Usually liver damage is affected by dosage and drug delivery. ${ }^{25}$

In this study microscopic changes occurred becauses the $C$. gigantea root bark extract contains steroids that are anti-inflammatory, while saponins, terpenoids and coumarin are antioxidants. Excessive use of anti-inflammatary drugs can be toxic, in contrast to hepatoprotective antioxidants in which antioxidants protect the liver from oxidative stress processes. ${ }^{26}$

Previous phytochemical investigations described the isolation and structural determination of a flavonoid. The flavonoid inhibitory activity in free radical production will give the hepatoprotective effect. The hepatoprotective effect also can be mediated by the inhibition of enhancement of glycoprotein biosynthesis, stabilization of cell membrane, UDP-sugar derivatives, and inhibition of lipid accumulation by its hypolipidemic property. ${ }^{27}$

\section{CONCLUSION}

Based on the results of the research, it can be concluded that the extract of $C$. gigantea root bark tested in male rats did not cause death and behavioral changes. Thus, it can be considered safe, but still it is hepatotoxic in higher doses. Extract of $C$. gigantea root bark had $\mathrm{LD}_{50}>5000 \mathrm{mg} / \mathrm{kg}$ orally, hence it could be stated as non-lethal. But, histopathologically, it showed some effects on parenchymatous degeneration on dosage of $1250 \mathrm{mg} / \mathrm{kg}$, hydropic degeneration on dosage $2500 \mathrm{mg} / \mathrm{kg}$, and hepatic necrosis on $5000 \mathrm{mg} / \mathrm{kg}$.

\section{ACKNOWLEDGEMENTS}

Our thanks go to Syiah Kuala University, Directorate of Research and Community Service, Ministry of Research, Technology and Higher Education for providing funds to support this research (No. 105/SP2H/LT/DPRM/IV/2017; dated 3rd of April 2017).

\section{CONFLICT OF INTEREST}

We wish to confirm that there are no known conflicts of interest associated with this publication and there has been no significant financial support for this work that could have influenced its outcome.

\section{REFERENCES}

1. Kumar, P., Suresh, E. and Kalavathy, S., 2013. Review on a potential herb Calotropis gigantea (L.) R. Br. Sch. Acad. J. Pharm. 2, 135-143.

2. Sarkar, S., Chakraverty, R. and Ghosh, A., 2014. Calotropis Gigantea Linn.- a complete busket of Indian traditional medicine. Int. J. Pharm. Res. Sci. 2, 7-17.

3. Kadiyala M., Ponnusankar S. and Elango K., 2013. Calotropis gigantiea (L.) R. $\mathrm{Br}$ (Apocynaceae): $\mathrm{A}$ phytochemical and pharmacological review. $J$. Ethnopharmacol. 150, 32-50.

4. Mandal S.C., 2017. Evaluation of anti-inflammatory and antinociceptive activity of methanol extract of Calotropis gigantea root. Int. J. Green Pharm. Sep 14; 11(03).

5. Elakkiya P. and Prasanna G., 2012. A study on phytochemical screening and invitro antioxidant activity of Calotropis gigantea L. Int. J. Pharmtech. Res. 4, 1428-31.

6. Habib M.R., and Karim M.R., 2016. Chemical characterization and insecticidal activity of Calotropis gigantea L. flower extract against Tribolium castaneum (Herbst). Asian Pac. J. Trop. Dis. 6, 996-9.

7. Singhi M., Purohit A. and Chattopadhyay S., 2015. Effectiveness and feasibility of methanol extracted latex of Calotropis procera as larvicide against dengue vectors of western Rajasthan, India. J. Vector Borne Dis. 52, 142.

8. Tsala D.E., Nga N., Thiery B.N., Bienvenue M.T. and Theophile D., 2015. Evaluation of the antioxidant activity and the healing action of the ethanol extract of Calotropis procera bark against surgical wounds. J. Intercult Ethnopharmacol. Jan, 4, 64.

9. Mohaimenul I.M., Ismail H.M., Abu O.M., Abdul A.M., Rowshahul H.M. and Rezaul K.M., 2012. A terpenoid and a steroid from Calotropis gigantea (L.). Int. J. Phys. Sci. 1, 580-584.

10. Vaiyapuri P.S., Ali A.A., Mohammad A.A., Kandhavelu J. and Kandhavelu M., 2015. Time lapse microscopy observation of cellular structural changes and image analysis of drug treated cancer cells to characterize the cellular heterogeneity. Environ. Toxicol. 30, 724-34.

11. Siddiqui M.F., Waghmare S.P., Mode S.G., Rekhate D.H., Kolte S.W., Hajare S.W. and Ali S.S., 2017. PhytoPharmacological study and therapeutic efficacy of Calotropis procera (Flower) against theileriosis in cattle. J. Anim. Res. 7, $757-62$. 
12. Mushir A., Jahan N., Ahmed A., 2016. A review on phytochemical and biological properties of Calotropis gigantea (Linn.) R. Br. Discovery. Phytomedicine. 3, 15.

13. Villasenor Alva, J. A., and Estrada, E. G., 2009. A generalization of Shapiro-Wilk's test for multivariate normality. Communications in Statistics-Theory and Methods, 38, 1870-1883.

14. Nordstokke, D. W., and Zumbo, B. D. , 2010. A new nonparametric Levene test for equal variances. Psicologica: Int. J. Meth. and Exper. Psych. 31, 401-430.

15. Gupta D., Dubey J. and Kumar M., 2016. Phytochemical analysis and antimicrobial activity of some medicinal plants against selected common human pathogenic microorganisms. Asian Pac. J. Trop. Dis. 6, 15-20.

16. Alluri N. and Majumdar M., 2014. Phytochemical analysis and in vitro antimicrobial activity of Calotropis gigantea, Lawsonia inermis and Trigonella foecum-graecum. Int. J. Pharm. Sci. 6, 524-7.

17. Roenigk, M., 2009. Histological Patterns in Drug Induced Liver Dissease. J. Clin. Path. [serial online], 481-492.

18. Luedde T., Kaplowitz N. and Schwabe R.F., 2014. Cell death and cell death responses in liver disease: mechanisms and clinical relevance. Gastroenterology. 147, 765-83.

19. Choy K.W., Kogilavani S., Norshalizah M., Rani S., Aspalilah A., Farihah H.S., Faizah O., Norzana A.G. and Das S., 2013. Anomalous structures of the liver: an anatomical insight. Clin. Ter. 164, 197-201.
20. Guicciardi M.E., Malhi H., Mott J.L. and Gores GJ., 2013. Apoptosis and necrosis in the liver. Compr Physiol. 2013 Apr 1.

21. Chen M., Zhang J., Wang Y., Liu Z., Kelly R., Zhou G., Fang H., Borlak J. and Tong W., 2013. The liver toxicity knowledge base: a systems approach to a complex end point. Clin. Pharmacol. Ther. 93, 409-12.

22. Hayes A.W. and Kruger C.L., 2014. Hayes' principles and methods of toxicology. Crc Press; 2014 Oct 10.

23. Kshirsagar A., 2010. Acute and Subacute Toxicity Study of The Ethanolic Extract from Calotropis Gigantea R.BR. In Rodents. Int. J. Pharma. Bio. Sci.

24. Jarrar B.M. and Taib N.T., 2012. Histological and histochemical alterations in the liver induced by lead chronic toxicity. Saudi. J. Biol. Sci. 19, 203-10.

25. Apte U., Gkretsi V., Bowen W.C., Mars W.M., Luo J.H., Donthamsetty S., Orr A., Monga S.P., Wu C. and Michalopoulos G.K., 2009. Enhanced liver regeneration following changes induced by hepatocyte-specific genetic ablation of integrin-linked kinase. Hepatology. 50, 844-51.

26. Chavda R., Vadalia K.R. and Gokani R.L., 2010. Hepatoprotective and antioxidant activity of root bark of Calotropis procera R. Br (Asclepediaceae). Int. J. Pharm. 6, 937-43.

27. Deshmukh P., Nandgude T., Rathode M.S., Midha A. and Jaiswal N., 2008. Hepatoprotective activity of Calotropis gigantea root bark experimental liver damage induced by Dgalactosamine in rats. Int. J. Pharm. Sci. Nanotechnol. 1, 281-6. 